УДК 631.895

https://doi.org/10.32634/0869-8155-2020-335-2-61-63

Бузетти К.Д.,

Иванов М.В.

Московский государственный университет технологий и управления им. К.Г. Разумовского (МГУТУ)

Россия, г. Москва

E-mail: mihail-ivanov90@list.ru

Ключевые слова: фильтрование, гидродинамическое обезвоживание, конвективная сушка, гумус, гранулирование.

Для цитирования: Бузетти К.Д., Иванов М.В. Получение жидких и гранулированных органических удобрений из отходов птицефабрик // Аграрная наука. 2020; (2): 61-63.

DOI: $10.32634 / 0869-8155-2020-335-2-61-63$

Konstantin D. Buzetti, Mikhail V. Ivanov

Moscow State University of Technology and Management named after K.G. Razumovsky (MGUTU)

Moscow, Russia

Key words: filtration, hydrodynamic dehydration, convective drying, humus, granulation.

For citation: Buzetti K.D., Ivanov M.V. Production of liquid and granulated organic fertilizers from poultry farm wastes // Agrarian Science. 2020; (2): 61-63. (In Russ.)

DOI: 10.32634/0869-8155-2020-335-2-61-63

\section{Получение жидких}

\section{и гранулированных органических удобрений из отходов птицефабрик}

\section{PЕЗЮME}

Актуальность и методика. В работе показана необходимость переработки отходов птицефабрик в органические удобрения. Рассмотрены основные аспекты переработки отходов птицефабрик. Описана и показана технологическая блок-схема получения из отходов птицефабрик высокоэффективных гранулированных и жидких органических удобрений. Рассмотрены ожидаемые результаты от реализации разработанной технологии.

Результаты. Технология переработки отходов птицефабрик предлагаемым способом позволяет получать как твердые гранулированные, так и жидкие органические удобрения. В то же время увеличивается энергоэффективность переработки отходов, уменьшается себестоимость основной продукции птицефабрик, минимизируется экологический риск попадания отходов в окружающую среду.

\section{Production of liquid and granulated organic fertilizers from poultry}

\section{farm wastes}

\section{ABSTRACT}

Relevance. The work shows the need for processing waste from poultry farms into organic fertilizers. The main aspects of poultry waste processing are considered. The scheme for obtaining high-efficiency granular and liquid organic fertilizers from waste from poultry farms is described and shown. Expected results from the implementation of the developed technology are considered.

Results. The technology of waste processing allows you to get both solid granular and liquid organic fertilizers. At the same time, the energy efficiency of waste processing is increased, the cost of the main products of poultry farms is reduced, and the environmental risk of waste entering the environment is minimized. 


\section{Введение}

Одной из главных задач в сельскохозяйственном производстве для многих регионов России является сохранение и воспроизводство плодородия почв. Воздействие человека в процессе сельскохозяйственного использования земель ухудшает параметры свойств почв, при этом значительно уменьшаются запасы гумуса, окисляется почвенная среда, ухудшаются ее физические, биологические и фитосанитарные свойства. Снижение плодородия сельскохозяйственных культур связано также с получением урожая без внесения удобрений только за счет почвенных ресурсов. Главными причинами этого являются рост цены на минеральные удобрения, слабое экономическое положение средних и мелких хозяйств, отсутствие передовых технологий переработки и использования органических удобрений. В Российской Федерации, по данным Минсельхоза, органические удобрения используют только на $6 \%$ территории. При этом органические удобрения часто применяют в непереработанном виде, т.е. вносят в почву без обработки. По мнению Минсельхоза, ученых и руководителей предприятий, в России наблюдается дефицит высококачественных экологически чистых органических удобрений в количестве не менее 300 тыс. т в год. Эксперты Минсельхоза прогнозируют ежегодный рост сельскохозяйственного производства в России на уровне от 5 до 7\%, следовательно, ежегодно пропорционально должно увеличиваться и количество удобрений.

Куриный помет является одним из наиболее эффективных органических удобрений. Для крупных птицефабрик эвакуация и переработка отходов - достаточно сложная и до конца не решенная проблема. Это приводит к тому, как показано в работах [1, 2], что ежедневно в регионе, где расположена птицефабрика, образуется большое количество сырого помета, вследствие этого происходит экологическое загрязнение окружающей среды, следовательно, отходы птицеводческих хозяйств необходимо утилизировать. Использование куриного помета в непереработанном виде в качестве органического удобрения способствует загрязнению полей сорняками, патогенной микрофлорой, яйцами гельминтов и пестицидами, что делает невозможным выращивание экологически безопасной сельскохозяйственной продукции. Как показано в статьях $[3,4]$, куриный помет представляет собой сложную смесь, содержащую различные органические и минеральные вещества, являющуюся ресурсом для получения органических удобрений, увеличивающих урожайность до 25-30\% в зависимости от культуры, природных условий и места произрастания. Поскольку от 45 до 50\% питательных веществ птичьего корма не перерабатывается и выделяется с экскрементами, то переработанный куриный помет [1] может также использоваться в качестве белковой замены комбикорма для кормления молодых сельскохозяйственных животных. Он содержит белки, жиры, легко- и трудногидролизуемые полисахариды, восстановительные вещества, макро- и микроэлементы, необходимые для роста и развития животных и растений.

\section{Методика}

Наиболее приемлемым способом переработки отходов птицеводства, позволяющим получать экологически безопасные удобрения, в настоящее время является конвективная тепловая сушка [3], которая осуществляется в барабанных сушилках, в сушилках с псевдоожиженным слоем и распылительных сушилках Недостатком этого метода являются высокие экономические затраты на удаление влаги из пометной массы. Содержание влаги на выходе из птицефабрики и при поступлении в сушильную установку достигает от 75 до $80 \%$, хотя влажность свежего куриного не должна превышать 70-72\%. В работе [1] было установлено, что увеличение влажности объясняется тем, что поилки часто засоряются пищей, при этом вода попадает в сток. Также в работах авторов [2] показано, что для переработки требуется свежий куриный помет, хранение которого должно составлять не более 12-25 часов.

Анализ существующих технологий переработки птичьего помета в России, представленный в работе [4], показывает, что при существующих различиях все они связаны с высокими экономическими затратами энергии и необходимостью специального оборудования, что неприемлемо для большинства хозяйств со слабой экономической базой. Ряд иностранных компаний производят как жидкие, так и гранулированные удобрения, но их методы производства также недостаточно эффективны. На российском рынке в настоящее время в промышленных объемах отсутствуют жидкие органические удобрения. Это самое главное конкурентное преимущество для создания технологии высокоэффективных органических удобрений из отходов птицефабрик, позволяющее занять свою нишу на внутреннем и, возможно, внешнем рынках. Стоимость 1 тонны органического удобрения на мировом рынке составляет около 490 долларов (источник - каталог «Компас», производитель "Greenvale farm Itd”, Англия).

Для переработки отходов птицефабрик необходима комбинированная энергосберегающая технология, отвечающая следующим требованиям: экологическая безопасность производства, т.е. минимизация степени влияния технологии переработки на окружающую среду; отсутствие необходимости использования адсорбирующих материалов и наполнителей (торфа, соломы, опилок, минералов, таких как бишофит, оксид кальция и др.); минимизация объемов строительства технологического оборудования; относительно низкая технологичность и окупаемость инвестиций за счет реализации продукта переработки. Данная технология должна позволить значительно снизить себестоимость продукции (мясо, молоко, яйца, куры), практически полностью исключить экологический риск, где основным фактором является полное использование продукции птицефабрик.

\section{Результаты}

Предложенная авторами энергосберегающая технология производства твердых и жидких органических удобрений основана на современных методах обезвоживания исходной смеси структурированной воды, входящей в состав органических молекул. Данная технология включает следующие основные этапы технологического процесса:

- для гранулированных удобрений: гидромеханическое разделение; механическое разделение; высокотемпературная сушка; стерилизация и гранулирование;

- для жидких органических удобрений: фильтрование, ультразвуковая и ультрафиолетовая дезинфекция; на последнем этапе осуществляется розлив продукции в тару и упаковка тары.

Технологическая блок-схема производства твердых и жидких органических удобрений представлена на рисунке. 


\section{Выводы}

Данная технология позволяет при существенном снижении энергозатрат обогащать конечный продукт минералами. Принципиально важным также является то, что снижение себестоимости конечного продукта проходит за счет новых методов переработки, которые сопровождаются повышением экологической безопасности на основе новых технических решений. Инновационная составляющая предлагаемой технологии состоит в том, что данная технология направлена на повышение энергоэффективности, а весь технологический комплекс - на увеличение функциональных возможностей. Отличительной особенностью этой технологии является то, что помимо твердых гранулированных органических удобрений производится жидкое органическое удобрение которое обезвреживается от патогенной флоры ультразвуковой и ультрафиолетовой стерилизацией. Ожидаемые результаты от реализации разработанной технологии заключаются в следующем: переработка отходов птицефабрик по данной технологии позволяет получать как твердые, так и жидкие органические удобрения; снижается себестоимость готового продукта; технология производства удобрений обеспечивает возможность увеличения содержания минеральных компонентов до оптимального уровня для конкретных почв; концентрация полезных ингредиентов в 2-3 раза больше, чем у аналогов, предлагаемых на рынке орга-

\section{ЛИТЕРАТУРА}

1. Бузетти К.Д., Иванов М.В. Исследование кинетических закономерностей процесса сушки отходов птицеводческих хозяйств с целью дальнейшей разработки технологии получения высокоэффективных органических удобрений и кормов для сельскохозяйственных животных // Аграрная наука. 2019. № 2. C. 71-73.

2. Калошин Ю.А., Светлов Ю.В., Бузетти К.Д. и др. Тепло- и массообмен при получении эффективных органических удобрений и продуктов для комбинированного производства: сборник научных статей 1-х Международных Лыковских научных чтений, посвященных 105-летию академика А.В. Лыкова. М.: Университетская книга, 2015. С. 187-190.

3. Бузетти К.Д., Кавецкий Г.Д. Технология сушки. М.: КолоС, 2012. $255 \mathrm{c}$.

4. Калошин Ю.А., Бузетти К.Д., Светлов Ю.В. Создание технологии получения высокоэффективных кормов и удобрений на базе использования сложных гетерогенных систем // Технологии XXI века в пищевой, перерабатывающей и легкой промышленности. 2014. № 9. 172 с.

\section{ОБ АВТОРАХ}

Бузетти Константин Дантевич, кандидат технических наук, доцент

Иванов Михаил Владимирович, старший преподаватель нических удобрений; удобрение дезинфицируется от устойчивых патогенных микроорганизмов, вирусов, гельминтных яиц, не содержит микробиологической флоры, анаэробов и семян сорняков; производство экологически безвредно; уменьшается время окупаемости проекта и его внедрения в производственный цикл; минимизируется экологический риск попадания отходов птицефабрик в окружающую среду; после окупаемости внедрения проекта в производство снижается себестоимость основной продукции птицефабрик.

\section{REFERENCES}

1. Buzetti K.D., Ivanov M.V. A study of the kinetic laws of the drying process of poultry farm waste with the aim of further developing the technology for producing highly effective organic fertilizers and feed for farm animals // Agrarian science. 2019. № 2. P. $71-73$.

2. Kaloshin Yu.A., Svetlov Yu.V., Buzetti K.D. et al. Heat and mass transfer upon receipt of effective organic fertilizers and products for combined production: collection of scientific articles of the 1st International Lykov Scientific Readings dedicated to the 105th anniversary of academician A.V. Lykova. M.: University Book, 2015. P. $187-190$

3. Buzetti K.D., Kavetsky G.D. Drying Technology. M, 2012. $255 p$

4. Kaloshin Yu.A., Buzetti KD, Svetlov Yu.V. Creation of a technology for producing highly effective feed and fertilizer based on the use of complex heterogeneous systems // Technology of the XXI century in the food, processing and light industries. 2014. № $9.172 \mathrm{p}$.

\section{ABOUT THE AUTHORS}

Konstantin D. Buzetti, Candidate of Technical Sciences, associate professor

Mikhail V. Ivanov, Senior Lecturer 